\title{
PENGARUH ORIENTASI TEKNOLOGI DAN ORIENTASI PASAR TERHADAP KINERJA PERUSAHAAN
}

\author{
Ni Wayan Novita Diah Lestari ${ }^{1}$ \\ I Gde Ketut Warmika ${ }^{2}$
${ }^{1,2}$ Fakultas Ekonomi dan Bisnis Universitas Udayana, Bali, Indonesia email: novitadiah45@gmail.com

\begin{abstract}
ABSTRAK
Penelitian ini dilakukan di Kecamatan Ubud pada bulan Desember 2018 hingga Januari 2019 dengan menggunakan responden pengelola hotel melati. Jumlah sampel yang diambil adalah sebanyak 90 responden dengan metode non probability sampling, yaitu purposive sampling. Penerapan orientasi teknologi dan orientasi pasar diukur menggunakan kuesioner. Alat analisis yang digunakan pada penelitian ini yaitu uji statistik deskriptif dan uji statististik regresi linear berganda. Hasil penelitian menunjukan bahwa orientasi teknologi dan orientasi pasar berpengaruh positif dan signifikan terhadap kinerja perusahaan. Motivasi pengelola hotel melati di Kecamatan Ubud terhadap pemanfaatan teknologi sangat tinggi. Faktor pendorong motivasi pemanfaatan teknologi dengan skor rata-rata tertinggi adalah kemudahan dalam mengoperasionalkan. Orientasi pelanggan merupakan salah satu indikator dalam variabel orientasi pasar yang memiliki pengaruh positif dan signifikan terhadap kinerja perusahaan, sehinggaa dapat disimpulkan bahwa meningkatkan kinerja perusahaan dapat dilakukan dengan memuaskan kebutuhan pelanggan dan selalu memperhatikan selera pelanggan.
\end{abstract}

Kata kunci: orientasi teknologi, orientasi pasar, kinerja perusahaan

\begin{abstract}
This research was conducted in Ubud Subdistrict in December 2018 to January 2019 using respondents to the management of the budget hotel. The number of samples taken is as many as 90 respondents with non probability sampling method, namely purposive sampling. The application of technology orientation and market orientation was measured using a questionnaire. The analytical tool used in this study is descriptive statistical test and statistical multiple linear regression test. The results of the study show that technology orientation and market orientation have a positive and significant effect on company performance. The motivation of managers of budget hotels in Ubud District towards the use of technology is very high. The motivating factor for using technology with the highest average score is ease in operationalizing. Customer orientation is one indicator in market orientation variables that has a positive and significant influence on company performance, so it can be concluded that improving company performance can be done by satisfying customer needs and always paying attention to customer tastes.
\end{abstract}

Keywords: technology orientation, market orientation, company performance 


\section{PENDAHULUAN}

Pariwisata telah menjadi motor penggerak perekonomian di berbagai negara di dunia. Daerah-daerah yang menjadi tujuan wisata memiliki peluang besar tumbuh suburnya fasilitas penunjang seperti penyediaan akomodasi, restoran, cindera mata, transportasi dan lain-lain. Bali menjadi salah satu provinsi yang paling banyak dikunjungi oleh wisatawan. Bali memiliki beberapa daerah dengan kegiatan kepariwisataan yang berperan dalam kehidupan perekonomian. Salah satunya daerah tersebut adalah Kecamatan Ubud, dengan daya tarik wisata dengan potensi besar dalam kepariwisataan khususnya di Kabupaten Gianyar dan Provinsi Bali pada umumnya.

Ubud memiliki keunikan daya tarik wisata berbasis panorama alam dan kesenian serta kehidupan keseharian masyarakat yang kental akan budaya dan adat istiadat setempat. Keunikan ini menginspirasi seniman khususnya pelukis asing untuk menetap dan berkarya di Ubud antara lain Antonio Blanco, Han Snel, dan Arie Smit yang karya-karya mereka menggambarkan potensi alam dan sosial budaya Ubud. Daya tarik ini menarik penyelenggara festival kelas dunia untuk mengadakan acaranya di Ubud seperti Ubud Writers \& Readers Festival, Ubud Food Festival, Bali Spirit Festival, dan Ubud Village Jazz Festival. Selain itu, Ubud mendapat promosi dalam dunia perfilman melalui film Hollywood "Eat, Pray, Love" yang dibintangi oleh Julia Roberts dengan latar belakang suasana Ubud. Chen dkk. (2015) menulis bahwa film ini meningkatkan popularitas Bali dan Ubud pada khususnya, sebagai destinasi pariwisata di kalangan wisatawan mancanegara yang berimbas pada berkembangnya usaha perhotelan.

Hotel sebagai tempat bagi wisatawan untuk menginap selama berwisata adalah salah satu industri yang penting dalam menunjang pariwisata. Peraturan Menteri Pariwisata Dan Ekonomi Kreatif Republik Indonesia (2013) memaparkan bahwa jenis hotel terbagi menjadi dua, yaitu: hotel bintang dan hotel nonbintang. Hotel bintang dibagi menjadi golongan kelas tertinggi hotel bintang lima hingga terendah hotel bintang satu, sedangkan hotel nonbintang tidak memiliki penggolongan kelas dan dapat disebut sebagai hotel melati. Kedua jenis hotel tersebut ditentukan berdasarkan skor penilaian persyaratan dasar, kriteria mutlak, serta kriteria tidak mutlak. Hotel yang memperoleh skor dalam rentang nilai tertinggi akan masuk ke dalam kelas hotel bintang lima, dan rentang nilai terendah akan masuk ke dalam kelas hotel melati. Hotel melati menurut Kamus Besar Bahasa Indonesia (KBBI) adalah hotel dengan tarif sederhana. Hotel melati adalah other star hotel yaitu suatu usaha akomodasi yang menggunakan suatu bangunan atau sebagian bangunan yang disediakan secara khusus, di mana setiap orang dapat menginap, makan, memperoleh pelayanan dan menggunakan fasilitas lainnya dengan pembayaran, dan belum memenuhi persyaratan sebagai hotel berbintang seperti yang ditentukan Direktorat Jenderal Pariwisata tetapi telah memenuhi kriteria hotel melati yang dikeluarkan oleh Dinas Pariwisata Daerah (Diparda). Ragam usaha hotel yang berada di Kecamatan Ubud tidak hanya hotel yang sudah dikenal luas dan berjejaring internasional seperti diantaranya Four Seasons Sayan, Amandari, Kayumanis, Uma Ubud, dan Warwick Ibah yang berada dalam kelas hotel bintang, tetapi juga hotel melati yang sebagian besar merupakan usaha hotel yang dimiliki oleh masyarakat lokal. 
Saat ini penggunaan teknologi oleh wisatawan telah banyak digunakan. Teknologi merupakan salah satu faktor yang mempengaruhi kesuksesan produk baru, dimana dengan menggunakan teknologi yang canggih, perusahaan dapat, menciptakan produknya menjadi lebih baik atau lebih inovatif. Teknologi yang paling sering digunakan oleh wisatawan adalah teknologi informasi internet. Perkembangan ini ditegaskan oleh Law \& Bai (2010) yang menyatakan bahwa dengan internet wisatawan dimudahkan untuk mengakses informasi tentang produk pariwisata tanpa terhalang jarak dan waktu. Internet adalah channel yang ideal untuk promosi industri pariwisata karena industri pariwisata sangat bergantung pada kelancaran informasi dari penyedia produk pariwisata kepada wisatawan. Industri perhotelan memanfaatkan keunggulan internet ini sebagai tempat untuk promosi dan berjualan. Buhalis \& Law (2001) menyatakan bahwa industri perhotelan menggunakan internet untuk mengkomunikasikan, mendistribusikan dan memasarkan produk mereka kepada wisatawan di seluruh dunia dengan biaya dan waktu yang efisien. Keberadaan internet menjadi media penghubung langsung antara pihak usaha hotel dengan wisatawan, memotong jalur perantara sehingga menyebabkan peran mereka menjadi berkurang. Keunggulan biaya dan waktu yang efisien menarik perhatian usaha hotel untuk menginvestasikan sumber daya mereka untuk hadir di internet dalam bentuk situs web hotel dan memanfaatkannya untuk menyampaikan materimateri promosional kepada wisatawan (Law \& Bai, 2010). Internet memberikan kekuatan bersaing kepada pelaku usaha hotel skala kecil seperti kelas hotel melati untuk bisa melakukan usaha promosi setara dengan kelas hotel bintang dan hotel berjejaring dunia dalam hal luas jangkauan materi promosional. Web hotel yang dibangun oleh pihak hotel sebagai bentuk kehadiran di internet selain digunakan sebagai media promosi juga sebagai media penjualan. Penelitian oleh Park \& Gretzel (2006) menyatakan bahwa pengelola hotel lebih memilih untuk menjual kamar-kamar melalui web hotel mereka sendiri dibandingkan dengan menjualnya melalui pihak perantara karena fleksibilitas dalam perencanaan harga penjualan kamar sulit didapat jika bekerja sama dengan perantara. Dengan menjual melalui web hotel milik mereka sendiri, wisatawan akan mendapatkan harga kamar yang lebih baik, dan pihak hotel berpeluang untuk mendapatkan pemasukan lebih besar dengan menawarkan promosi penjualan paket menginap, dinner, tour, dan sebagainya dalam web hotel. Oleh karena itu, pada era sekarang, dalam persaingan bisnis secara global, khususnya usaha hotel, pemanfaatan teknologi internet melalui web hotel merupakan faktor yang menguntungkan bagi pihak hotel untuk menggapai keunggulan kompetitif.

Orientasi pasar adalah budaya organisasi yang paling efektif dan efisien dalam menciptakan perilaku yang diperlukan untuk menghasilkan nilai superior bagi pembeli, dengan demikian kinerja bisnis yang unggul terus menerus dapat tercapai (Narver \& Slater, 1990). Konsep orientasi pasar menurut Hasan (2014) merupakan konsep peralihan dari konsep sebelumnya, yaitu konsep orientasi produk, orientasi pasar ini diyakini sebagai upaya pemasaran untuk mencegah terjadinya penurunan penjualan, yang dimana fokus orientasi pasar ini adalah perencanaan strategis sebuah unit bisnis yang harus memenuhi tiga tuntutan, (1) semua fungsi yang ada dalam perusahaan mampu menyerap semua informasi penting yang mempengaruhi pembelian, (2) keputusan pembuatan strategi 
dilakukan secara interfungsional dan interdivisional, (3) divisi dan fungsi melakukan koordinasi yang baik dan memiliki sense of commitment dalam melaksanakan kegiatan pemasaran. Tjiptono (2014) mengatakan dalam kaitannya dengan persaingan, setiap perusahaan perlu memahami siapa pesaingnya, bagaimana posisi produk/pasar pesaing tersebut, apa strategi mereka, kekuatan dan kelemahan pesaing agar perusahaan dapat menjadi berorientasi pasar.

Hartini (2017) mendefinisikan orientasi pasar sebagai budaya organisasi yang mengarah pada pasar, dan menyatakan bahwa orientasi pasar menjadi variable antecedent dari keunggulan bersaing, dan kinerja perusahaan, yang dimana perusahaan yang berorientasi pasar akan berfokus pada pemahaman keinginan dan kebutuhan pelanggan saat ini dan masa akan datang dan berfokus pada memahami kekuatan dan kelemahan jangka pendek pesaingnya, kapabilitas jangka panjang pesaingnya, serta strategi saat ini dan mendatang dari pesaing-pesaingnya. Helia et al. (2015) menyatakan orientasi pasar terdiri atas empat dimensi yaitu orientasi pelanggan mencakup semua aktivitas yang berkontribusi pada pemahaman perusahaan terhadap kebutuhan dan preferensi para pelanggan sasarannya dan pada kemampuan perusahaan untuk merancang produk dan jasa yang bisa memuaskan kebutuhan dan preferensi tersebut; orientasi pesaing mencerminkan pemahaman tentang kekuatan dan kelemahan jangka pendek dan kapabilitas dan strategi jangka panjang para pesaing utama saat ini dan pesaing potensial perusahaan, serta kemampuan merespon aktivitas dan strategi pesaing; koordinasi antar fungsi mengacu pada tingkat koordinasi antarfungsi atau departemen berbeda dalam sebuah perusahaan dan tingkat penyebarluasan informasi antardepartemen; dan orientasi laba meliputi pemantauan dan pemahaman terhadap profitabilitas masingmasing kategori produk individual dan produk pemasok.

Kinerja (performance) merupakan suatu pencapaian hasil kerja seseorang maupun kelompok orang dalam suatu organisasi dan suatu periode waktu tertentu sesuai dengan lingkup tanggung jawab dan wewenang masing-masing sebagai upaya mencapai tujuan organisasi dan dilakukan sesuai dengan moral dan etika serta secara legal tanpa melanggar hukum. Secara konseptual, kinerja dapat dilihat dari dua sisi, yaitu kinerja organisasi dan kinerja individu. Kinerja organisasi adalah total dari hasil kerja yang dicapai oleh organisasi, sedangkan kinerja individu merupakan hasil kerja karyawan perusahaan atau perseorangan anggota organisasi. Pada dasarnya kinerja individu dan organisasi berhubungan erat satu sama lain. Pencapaian tujuan organisasi tentunya sangat dipengaruhi oleh sumber daya yang terdapat dalam organisasi termasuk anggota yang memiliki peran aktif sebagai pelaku dalam usaha untuk mencapai tujuan organisasi tersebut. Kinerja organisasi atau kinerja perusahaan merupakan indikator tingkat prestasi yang dapat dicapai dan mencerminkan keberhasilan manajer atau pengusaha (Soedjono, 2005). Kinerja adalah segala sistem yang berhubungan dengan aktivitas dan hasil (outcome) yang diperoleh. Setiap perusahaan berkepentingan untuk mengetahui prestasinya sebagai cermin dari keberhasilan usahanya dalam persaingan pasar, dengan kinerja pemasaran perusahaan dapat mengetahui dimana posisi keberhasilan perusahaan yang diukur dari setiap jangka waktu yang telah ditentukan (Mudiantono, 2005). Ferdinand (2010) mengemukakan kinerja perusahaan merupakan faktor yang umum digunakan untuk mengukur dampak dari sebuah strategi perusahaan. Strategi 
perusahaan selalu diarahkan untuk menghasilkan kinerja perusahaan seperti volume penjualan, porsi/pangsa pasar dan tingkat pertumbuhan penjualan maupun kinerja keuangan.

Penelitian ini bertujuan untuk mendalami Pengaruh Orientasi Teknologi dan Orientasi Pasar terhadap Kinerja Perusahaan hotel melati di Kecamatan Ubud. Alasan memilih hotel melati di Kecamatan Ubud karena Ubud sendiri merupakan destinasi wisata populer di Bali yang terkenal dengan nilai budayanya. Keunikan budaya dan keramahan masyarakat yang dimiliki oleh Ubud menjadi daya tarik bagi wisatawan yang berkunjung sehingga mayoritas dari wisatawan tersebut sangatlah nyaman dan menikmati perjalanan wisatanya saat berada di Ubud. Ditambah dengan keindahan alamnya seperti sawah dan sungai yang mempercantik keindahan dari Ubud itu sendiri. Banyaknya jumlah wisatawan yang datang, akan menguntungkan bagi para penyedia jasa akomodasi karena sebagian besar wisatawan tersebut pasti akan membutuhkan tempat menginap. Peluang ini yang dapat dimanfaatkan oleh penyedia jasa akomodasi seperti pondok wisata dalam usaha meningkatkan kinerjanya. Usaha akomodasi yang ada di Ubud sangatlah bervariasi, mulai dari Pondok Wisata, Hotel Melati, hingga hotel berbintang. Hotelhotel melati menggerakkan perekonomian masyarakat setempat dengan memanfaatkan peluang yang ditimbulkan oleh geliat pariwisata, baik sebagai pemilik hotel maupun sebagai tenaga kerja dalam usaha hotel.

Tabel 1.

Jumlah Usaha Hotel Menurut Klasifikasi dan Kecamatan di Kabupaten Gianyar Tahun 2015

\begin{tabular}{lcccccc}
\hline \multicolumn{1}{c}{ Kecamatan } & B. 1 & B. 2 & B. 3 & B. 4 & B. 5 & Melati \\
\hline Sukawati & 0 & 0 & 0 & 0 & 1 & 2 \\
Blahbatuh & 0 & 0 & 1 & 0 & 0 & 1 \\
Gianyar & 0 & 0 & 0 & 0 & 0 & 1 \\
Tampaksiring & 1 & 0 & 0 & 0 & 0 & 1 \\
Ubud & $\mathbf{1}$ & $\mathbf{0}$ & $\mathbf{6}$ & $\mathbf{6}$ & $\mathbf{6}$ & $\mathbf{9 0}$ \\
Tegallalang & 0 & 0 & 0 & 0 & 0 & 8 \\
Payangan & 0 & 0 & 0 & 1 & 1 & 3 \\
\hline
\end{tabular}

Sumber: Direktori Hotel Kabupaten Gianyar, 2016

Pada Tabel 1. usaha hotel yang mendominasi di Kabupaten Gianyar adalah usaha tipe hotel melati. Kecamatan Ubud adalah tempat yang paling banyak terdapat usaha tipe hotel melati. Itu dikarenakan Ubud merupakan destinasi wisata yang paling dicari oleh wistawan lokal maupun asing. Sehingga ini menjadi peluang besar bagi masyarakat setempat untuk membuat usaha tipe hotel melati yang akan membantu perekonomian mereka. Dalam rangka bersaing memperebutkan tamu (penyewa kamar), setiap hotel melakukan usaha-usaha menyebarluaskan informasi promosi untuk menarik tamu agar datang dan menyewa kamar di hotel mereka. Internet membantu penyebarluasan informasi promosi usaha hotel dan mempermudah penjualan. Lokasi ini akan menjadi sasaran utama untuk mengetahui bagaimana kinerja mereka jika dilihat dari variabel orientasi teknologi dan orieantasi pasar. 
Teknologi merupakan salah satu faktor yang mempengaruhi kesuksesan produk baru, dimana dengan menggunakan teknologi yang canggih, perusahaan dapat, menciptakan produknya menjadi lebih baik atau lebih inovatif. Teknologi tidak hanya terwujud dalam aktivitas primer melainkan juga dalam aktivitas pendukung seperti pembuatan desain dengan bantuan komputer merupakan wujud aplikasi teknologi yang banyak dipakai untuk menggantikan cara tradisional. Perubahan dalam teknologi akan membawa pengaruh yang besar terhadap banyak komponen di dalam masyarakat, melalui produk-produk, proses-proses dan sesuatu yang bersifat baru dan mampu menghasilkan kinerja organisasi yang lebih baik (Kara et al., 2005). Pemilihan teknologi meliputi institusi-institusi dan aktivitasaktivitas yang terlibat dalam menciptakan pengetahuan baru dan menerjemahkan pengetahuan itu ke output, produk, proses baru yang dapat memberikan manfaat lebih baik dari produk yang telah di hasilkan sebelumnya.. Perubahan teknologi yang cepat menjadi momentum bagi perusahaan untuk mengkaji segmen teknologi yang cepat dan menyeluruh. Langkah konkret dalam merespon teknologi ditunjukkan oleh perusahaan dengan komitmen terhadap peran riset dan pengembangan, mengadopsi teknologi baru yang lebih awal, penggunaan teknologi proses produksi yang sesuai dengan kebutuhan pasar, menghasilkan produk yang penuh inovasi dan memberi nilai yang terbaik bagi konsumen sehingga diperoleh pangsa pasar yang lebih tinggi dan perolehan laba yang lebih baik.

Orientasi pasar adalah kondisi dimana sebuah perusahaan dalam melakukan suatu keputusan berdasarkan kondisi riil di pasar dan melakukan pendekatanpendekatan pada pasar dengan cara penelitian dan memahami nilai-nilai yang berlaku (Pertiwi \& Siswoyo, 2016). Orientasi pasar meliputi kecenderungan perusahaan dalam memperoleh keunggulan melalui pemenuhan kebutuhan dan keinginan kosumen (Pramesti \& Giantari, 2016). Orientasi pasar merupakan faktor penting yang memungkinkan perusahaan memahami pasar dan mengembangkan strategi produk dan jasa untuk memenuhi kebutuhan pelanggan dan kebutuhan pasar. Perusahaan yang berorientasi pasar adalah posisi yang baik untuk mengembangkan dan meningkatkan posisi perusahaan menjadi lebih khas (relative terhadap persaingan) dalam jangka panjang (Kumar et al., 2011). Afsharghasemi et al. (2013) menyatakan perusahaan harus meyakinkan bahwa strategi yang sedang dikembangkan tidak boleh didahului oleh pesaing dalam membuat inovasi baru dan lebih baik dalam menyediakan kebutuhan serta keinginan konsumen. Organisasi yang berorientasi pada pasar dituntut lebih unggul, dapat merasakan kebutuhan dan keinginan pasar serta mampu merespon perubahan kebutuhan pasar (Rong et al., 2014). Orientasi pasar merupakan unsur pemersatu dari upaya dan kinerja individu dan departemen, yang mengarah ke kinerja yang lebih tinggi. Dengan demikian, semakin besar tingkat orientasi pasar perusahaan, semakin baik kinerjanya (Felgueiraa \& Gouvenia, 2012). Orientasi pasar diukur dalam 3 dimensi yaitu orientasi pesaing, orientasi pelanggan, dan koordinasi antar fungsi (Liu et al., 2013).

Orientasi pesaing adalah pemahaman mengenai kekuatan, kelemahan dan kemampuan dari pesaing (Narver \& Slater, 1990). Orientasi pesaing adalah kemauan perusahaan untuk memonitor strategi yang diterapkan para pesaingnya (Mulyani, 2015). Perusahaan yang berorientasi pada pesaing menghabiskan waktu 
mereka pada isu-isu yang lebih penting melalui gerakan pesaing dan pasar dan mencoba untuk menemukan kebijakan yang dapat diterapkan terhadap merek yang mereka produksi. Wulandari (2013) menyatakan bahwa, kemampuan manajemen mengenali pesaingnya akan membantu dan menggali berbagai informasi mengenai apa dan bagaimana pesaing menjalankan bisnis serta model strategi yang diterapkan, sehingga manajemen memperoleh kepastian bahwa strategi dan aktivitas apapun yang dilakukan oleh perusahaan tidak didahului oleh pesaingnya. Perusahaan yang berorientasi pada pesaing selalu memantau dan memperhatikan apa yang dilakukan oleh pesaing mereka dan berusa untuk mengembangkan dengan cara berinovasi dari produk yang sudah ada (Putri, 2015). Orientasi pesaing, akan mendorong perusahaan kepada beberapa perilaku seperti merespon tindakan pesaing yang mengancam, menyebarkan informasi ke dalam perusahaan mengenai strategi pesaing, memindai kekuatan dan kelemahan pesaing (Zhang \& Bruning, 2011). Orientasi pesaing berarti penjual memahami kekuatan dan kelemahan jangka pendek, kemampuan jangka panjang dan strategi kunci saat ini maupun strategi kunci potensial dari pesaing (Maslucha \& Sanaji, 2013)

Orientasi pelanggan adalah kemampuan untuk membantu pelanggan dalam menilai kebutuhan mereka dan mengarahkan pada keputusan yang tepat, memberikan layanan yang memenuhi kebutuhan pelanggan, dan menghindari taktik penjualan tekanan tinggi atau memaksa (Lee et al., 2011). Orientasi pelanggan adalah pemahaman yang cukup mengenai pembeli sasaran untuk dapat menciptakan superior value secara terus menerus (Umar, 2014). Organisasi yang berorientasi pada pelanggan selalu berusaha menjadi yang terdepan dengan menyesuaikan bauran pemasaran dengan pengetahuan tentang keinginan pasar atau pelanggan (Safarnia et al., 2011). Orientasi pelanggan adalah kecenderungan atau keinginan karyawan untuk memenuhi kebutuhan pelanggan dalam konteks tanggung jawab pekerjaan (Lee et al., 2013). Orientasi pelanggan adalah kebutuhan dan kemampuan untuk mengidentifikasi, menganalisis, memahami dan menanggapi kebutuhan pelanggan (Yazdani et al., 2011). Menurut Chiun et al., 2015) komponen orientasi pelanggan pada orientasi pasar dapat meningkatkan kepuasan pelanggan, meningkatkan produktifitas dan kualitas pelayanan organisasi yang mengarah pada kinerja yang lebih bai secara keseluruhan. Orientasi pelanggan merupakan pemahaman yang memadai atas pembeli sasaran agar mampu menciptakan nilai superior bagi perusahaan secara berkesinambungan (Maslucha \& Sanaji, 2013).

Koordinasi antar fungsional menunjukkan koordinasi sumber daya perusahaan dan kegiatan pelanggan terkait di seluruh perusahaan (Zhou et al., 2009). Koordinasi antarfungsi menjadi sangat penting bagi kelangsungan perusahaan yang ingin memberikan kepuasan kepada pelanggan sekaligus memenangkan persaingan dengan cara megoptimalkan fungsi-fungsi yang ada dalam perusahaan secara cermat (Widarti, 2016). Koordinasi antarfungsional merupakan koordinasi sumber daya perusahaan terkait kegiatan pelanggan dan informasi pasar dalam rangka menciptakan nilai bagi pelanggan. Aspek koordinasi antarfungsional dalam orientasi pasar mempunyai fungsi dalam menghubungkan koordinasi antar jaringan dalam menggabungkan pikiran serta keterampilan anggota organisasi sehingga dapat menghasilkan suatu inovasi 
Kinerja atau performance adalah segala sistem yang berhubungan dengan aktivitas dan hasil (outcome) yang diperoleh. Herath \& Mahmood (2013) kinerja perusahaan didefinisikan sebagai perbandingan dari nilai yang diciptakan oleh perusahaan dengan harapan nilai yang lebih untuk perusahaan. Menurut Kanyabi \& Devi (2012) kinerja adalah pengukuran kemampuan keuangan perusahaan seperti tingkat keuntungan, tingkat investasi dengan kedua pertumbuhan penjualan dan laba. Mandy (2009) melihat kinerja sebagai hasil dari proses beradaptasi manajemen yang efektif. Kinerja organisasi dapat diukur dengan menggunakan sejumlah kriteria yang meliputi efektifitas, efisiensi, pertumbuhan dan produktivitas. Efektivitas perusahaan dapat digunakan untuk mengukur operasi, keuangan serta tingkat perilaku. Pertama, ukuran keuangan dapat mencakup profitabilitas dan pertumbuhan. Kedua, ukuran operasi mungkin termasuk kenalan sumber daya, tingkat produksi, pemasaran, sikap karyawan untuk bekerja dan sebagainya. Ketiga, perilaku efektif terdiri dari kemampuan beradaptasi karyawan, kepuasan dan interaksi yang baik dapat digunakan untuk menilai kinerja.

Olusola (2011) menjelaskan konsep kinerja sebagai kemampuan untuk menilai tingkat keberhasilan sebuah organisasi bisnis baik itu kecil atau besar. Kualitas kinerja perusahaan yang ditunjang oleh pemahaman terhadap konsumen dan keunggulan produk baru merupakan faktor-faktor yang dapat meningkatkan kesuksesan produk baru yang berhubungan dengan penciptaan nilai yang superior (superior value) bagikonsumen. Terciptanya superior value bagi konsumen merupakan batu loncatan bagi suatu perusahaan untuk meningkatkan kinerja pemasarannya. Ferdinand (2010) mengemukakan kinerja perusahaan merupakan faktor yang umum digunakan untuk mengukur dampak dari sebuah strategi perusahaan. Strategi perusahaan selalu diarahkan untuk menghasilkan kinerja perusahaan seperti volume penjualan, porsi/pangsa pasar dan tingkat pertumbuhan penjualan maupun kinerja keuangan.

Teknologi merupakan salah satu faktor yang mempengaruhi kesuksesan produk baru, dimana dengan menggunakan teknologi yang canggih, perusahaan dapat, menciptakan produknya menjadi lebih baik atau lebih inovatif(Voss \& Voss, 2000). Beberapa penelitian menunjukkan bahwa penggunaan teknologi informasi akan memberi manfaat kepada perusahaan. Buhalis \& Law (2001), menyatakan bahwa industri perhotelan menggunakan internet untuk mengkomunikasikan, mendistribusikan dan memasarkan produk mereka kepada wisatawan di seluruh dunia dengan biaya dan waktu yang efisien. Keberadaan internet menjadi media penghubung langsung antara pihak usaha hotel dengan wisatawan, memotong jalur perantara sehingga menyebabkan peran mereka menjadi berkurang. Hasil penelitian Wulandari (2015) yang menyatakan bahwa terdapat hubungan yang positif dan kuat antara teknologi informasi terhadap kinerja perusahaan, semakin tinggi orientasi teknologi, hasil kinerja perusahaan juga menjadi meningkat.

Berdasarkan pemikiran diatas, hipotesis yang dapat diajukan dalam penelitian ini adalah:

$\mathrm{H}_{1}$ : Orientasi teknologi memiliki pengaruh positif signifikan terhadap kinerja perusahaan. 
Temuan Jyoti \& Sharma (2012) dalam penelitian mereka pada orientasi pasar dan hubungan kinerja bisnis. Mereka menemukan adanya hubungan yang positif antara orientasi pasar terhadap kinerja bisnis. Ahimbisibwe et al. (2013) menemukan pengaruh positif antara orientasi pasar terhadap kinerja pada perusahaan ekspor buah di Udanda, disebutkan bahwa perusahaan yang inovatif cenderung melakukan lebih baik daripada perusahaan yang tidak inovatif karena melalui inovasi, perusahaan menghadap ke atas dengan perusbahan lingkungan pemasaran. Jayaningrum \& Sanawiri (2018) dalam penelitiannya menyatakan bahwa orientasi pasar berpengaruh positif signifikan terhadap kinerja yaitu semakin tinggi orientasi pasar maka derajat kinerja perusahaan semakin tinggi. Orientasi pasar mencerminkan kompetensi dalam memahami pelanggan, karena itu mempunyai peluang memberi kepuasan pada pelanggan Hasil temuan Adiputra \& Kusumadmo (2016) menemukan bahwa orientasi pasar (orientasi pada konsumen, orientasi pada pesaing, koordinasi antar fungsi) memiliki pengaruh yang positif dan signifikan terhadap kinerja perusahaan.

Berdasarkan pemikiran diatas, hipotesis yang dapat diajukan dalam penelitian ini adalah:

$\mathrm{H}_{2}$ : Orientasi pasar memiliki pengaruh positif signifikan terhadap kinerja perusahaan.

\section{METODE PENELITIAN}

Penelitian ini memilih lokasi di Kecamatan Ubud, khususnya mengenai kinerja dari tipe hotel melati yang ada di wilayah tersebut. Lokasi ini akan menjadi sasaran utama untuk mengetahui bagaimana kinerja mereka jika dilihat dari variabel orientasi teknologi dan orieantasi pasar.

Populasi dalam penelitian ini memiliki sifat terbatas dimana jumlah dan karakteristik dari responden penelitian sudah diketahui secara pasti. Populasi dalam penelitian ini adalah perusahaan tipe hotel melati yang ada di Kecamatan Ubud. Jumlah populasi dalam penelitian ini adalah 90 hotel. Dalam penelitian ini digunakan 18 indikator sehingga banyaknya responden yang digunakan untuk sampel adalah ( 5 x $18=90$ orang). Jadi, ukuran sampel 90 responden sudah dikategorikan layak.

Teknik analisis yang akan dipakai dalam penelitian ini adalah dengan memakai teknik analisis regresi linier berganda yaitu hubungan secara linear antara dua variabel atau lebih. Perhitungan variabel-variabel dalam penelitian ini menggunakan SPSS 18.0 software. Analisis regresi linear berganda digunakan untuk mengetahui arah hubungan antara variabel bebas terhadap variabel terikat apakah masing-masing variabel bebas berhubungan positif atau negatif. Tujuan analisis ini adalah untuk mengetahui pengaruh Orientasi Teknologi dan Orientasi Pasar terhadap Kinerja Perusahaan. Rumus dari analisis regresi berganda adalah sebagai berikut:

$$
\mathrm{Y}=\mathrm{a}+\mathrm{b}_{1} \mathrm{X}_{1}+\mathrm{b}_{2} \mathrm{X}_{2}+\mathrm{e}
$$

Keterangan:

$$
\mathrm{Y}=\text { Kinerja Perusahaan }
$$

a $\quad=$ Konstanta (nilai $\mathrm{Y}$ apabila $\mathrm{X}_{1}, \mathrm{X}_{2} \ldots . . \mathrm{X}_{\mathrm{n}}=0$ ) 


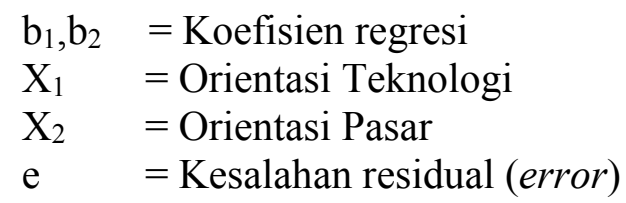

\section{HASIL DAN PEMBAHASAN}

Data penelitian diperoleh dari hasil kuesioner yang telah disebarkan kepada responden penelitian sejumlah 90 orang karyawan pada hotel melati di Kecamatan Ubud, Gianyar. Karakteristik responden meliputi jenis kelamin, usia, tingkat pendidikan responden, dan jabatan. Ringkasan mengenai karakteristik responden dapat dilihat pada Tabel 2 .

Tabel 2.

Karakteristik Responden

\begin{tabular}{cccc}
\hline Karakteristik Responden & Keterangan & $\begin{array}{c}\text { Jumlah } \\
\text { (Orang) }\end{array}$ & $\begin{array}{c}\text { Persentase } \\
(\mathbf{\%})\end{array}$ \\
\hline \multirow{3}{*}{ Jenis Kelamin } & Laki-Laki & 48 & 53,33 \\
& Perempuan & 42 & 46,67 \\
& Total & $\mathbf{9 0}$ & $\mathbf{1 0 0}$ \\
& 19-25 Tahun & 25 & 27,78 \\
Usia & 26-35 Tahun & 37 & 41,11 \\
& 36-45 Tahun & 16 & 17,78 \\
& >46 Tahun & 12 & 13,33 \\
& Total & $\mathbf{9 0}$ & $\mathbf{1 0 0}$ \\
& SMA/SMK & 21 & 23,33 \\
& Dilpoma & 29 & 32,22 \\
& S1 & 35 & 38,89 \\
& S2 & 5 & 5,56 \\
& Total & $\mathbf{9 0}$ & $\mathbf{1 0 0}$ \\
& Staff Front Office & 42 & 46,67 \\
& Staff Marketing & 31 & 34,44 \\
& Manager/Supervisor & 17 & 18,89 \\
& Total & $\mathbf{9 0}$ & $\mathbf{1 0 0}$ \\
\hline
\end{tabular}

Sumber: Data diolah, 2018

Profil jenis kelamin digunakan untuk mengetahui proporsi responden lakilaki dan perempuan. Responden laki-laki sebanyak 48 orang $(53,33 \%)$ dan responden perempuan sebanyak 42 orang (46,67\%). Informasi ini memberikan gambaran bahwa mayoritas karyawan pada hotel melati di Kecamatan Ubud, Gianyar adalah laki-laki.

Profil terkait usia menunjukkan kelompok umur karyawan yang bekerja pada hotel melati di Kecamatan Ubud, Gianyar. Karyawan dengan rentang usia 19 sampai 25 tahun sebanyak 25 orang $(27,78 \%$ ), karyawan dengan rentang usia 26 sampai 35 sebanyak 37 orang $(41,11 \%)$, karyawan dengan rentang usia 36 sampai 45 tahun sebanyak 16 orang $(17,78 \%)$, dan sisanya sebanyak 12 orang $(13,33 \%)$ adalah karyawan dengan rentang usia lebih dari 46 tahun. Hal ini menunjukkan bahwa dalam penelitian ini karyawan yang bekerja pada hotel melati di Kecamatan Ubud, Gianyar mayoritas berusia antara 26 sampai 35 tahun.

Profil jenjang pendidikan merupakan indikator untuk mengetahui tingkat pendidikan akhir responden. Tingkat pendidikan responden pada jenjang 
SMA/SMK yaitu sebanyak 21 orang karyawan (23,33\%), selanjutnya sebanyak 29 orang karyawan $(32,22 \%)$ memiliki tingkat pendidikan Diploma, sebanyak 35 orang karyawan $(38,89 \%)$ memiliki tingkat pendidikan Sarjana (S1), dan sisanya 5 orang karyawan (5,56\%) memiliki tingkat pendidikan Pasca Sarjana (S2). Informasi ini memberikan gambaran bahwa dalam penelitian ini karyawan yang bekerja pada hotel melati di Kecamatan Ubud, Gianyar mayoritas memiliki jenjang pendidikan Sarjana.

Profil jabatan merupakan indikator untuk mengetahui jabatan responden pada hotel melati di Kecamatan Ubud, Gianyar. Responden dengan jabatan staf front office adalah sebanyak 42 orang karyawan (46,67\%), selanjutnya responden dengan jabatan staf marketing sebanyak 31 orang karyawan $(34,44 \%)$, dan sisanya responden yang menjabat sebagai manager / supervisor sebanyak 17 orang karyawan (18,89\%). Informasi ini memberikan gambaran bahwa dalam penelitian ini karyawan pada hotel melati di Kecamatan Ubud, Gianyar yang berpartisipasi dalam pengisian kuisioner mayoritas adalah staff front office.

Suatu instrumen dalam penelitian dikatakan valid apabila mampu mengukur apa yang ingin diukur. Suatu instrumen dikatakan valid apabila memiliki koefisien korelasi antara butir dengan skor total dalam instrumen tersebut lebih besar dari 0,30 dengan tingkat kesalahan Alpha 0,05. Tabel 3 berikut menyajikan hasil uji validitas instrumen penelitian.

Tabel 3.

Rekapitulasi Hasil Uji Validitas Instrumen Penelitian

\begin{tabular}{cccccc}
\hline Variabel & Dimensi & Indikator & $\begin{array}{c}\text { Koefisien } \\
\text { Korelasi }\end{array}$ & $\begin{array}{c}\text { Sig. (2- } \\
\text { tailed })\end{array}$ & Keterangan \\
\hline Orientasi & & $\mathrm{X}_{1.1}$ & 0,824 & 0,000 & Valid \\
Teknologi & & $\mathrm{X}_{1.2}$ & 0,850 & 0,000 & Valid \\
$\left(\mathrm{X}_{1}\right)$ & & $\mathrm{X}_{1.3}$ & 0,840 & 0,000 & Valid \\
& & $\mathrm{X}_{1.4}$ & 0,802 & 0,000 & Valid \\
& & $\mathrm{X}_{2.1 \mathrm{a}}$ & 0,810 & 0,000 & Valid \\
& Orientasi & $\mathrm{X}_{2.1 \mathrm{~b}}$ & 0,807 & 0,000 & Valid \\
& Pelanggan & $\mathrm{X}_{2.1 \mathrm{c}}$ & 0,813 & 0,000 & Valid \\
& & $\mathrm{X}_{2.1 \mathrm{~d}}$ & 0,648 & 0,000 & Valid \\
Orientasi & & $\mathrm{X}_{2.2 \mathrm{a}}$ & 0,670 & 0,000 & Valid \\
Pasar & & $\mathrm{X}_{2.2 \mathrm{~b}}$ & 0,767 & 0,000 & Valid \\
$\left(\mathrm{X}_{2}\right)$ & Orientasi Pesaing & $\mathrm{X}_{2.2 \mathrm{c}}$ & 0,792 & 0,000 & Valid \\
& & $\mathrm{X}_{2.3 \mathrm{a}}$ & 0,707 & 0,000 & Valid \\
& & $\mathrm{X}_{2.3 \mathrm{~b}}$ & 0,795 & 0,000 & Valid \\
& Koordinasi & $\mathrm{X}_{2.3 \mathrm{c}}$ & 0,754 & 0,000 & Valid \\
& & $\mathrm{Y}_{1}$ & 0,802 & 0,000 & Valid \\
Kinerja & & $\mathrm{Y}_{2}$ & 0,784 & 0,000 & Valid \\
Perusahaan & & $\mathrm{Y}_{3}$ & 0,791 & 0,000 & Valid \\
$(\mathrm{Y})$ & & $\mathrm{Y}_{4}$ & 0,656 & 0,000 & Valid \\
\hline
\end{tabular}

Sumber: Data diolah, 2018 
Hasil uji validitas pada Tabel 3. menunjukkan bahwa seluruh instrumen penelitian yang digunakan untuk mengukur variabel orientasi teknologi, orientasi pasar, dan kinerja perusahaan memiliki nilai koefisien korelasi dengan skor total seluruh item pernyataan lebih besar dari 0,30 dengan signifikansi kurang dari 0,05. Hal ini menunjukkan bahwa butir-butir pernyataan dalam instrument penelitian tersebut valid dan layak digunakan sebagai instrument penelitian.

Uji Reliabilitas terhadap instrumen penelitian ini menggunakan nilai Alpha Cronbach, yakni untuk mengetahui unidimensionalitas butir-butir pernyataan terhadap variabel laten yang diteliti (orientasi teknologi, orientasi pasar dan kinerja perusahaan). Nilai Alpha Cronbach dinyatakan reliabel jika nilainya lebih besar atau sama dengan 0,60 . Rekapitulasi hasil uji reliabilitas instrumen penelitian dapat dilihat pada Tabel 4 berikut.

Tabel 4.

Rekapitulasi Hasil Uji Reliabilitas Instrumen Penelitian

\begin{tabular}{cccc}
\hline Variabel & Dimensi & Cronbach's Alpha & Keterangan \\
\hline Orientasi teknologi $\left(\mathrm{X}_{1}\right)$ & Orientasi & 0,824 & Reliabel \\
& Pelanggan & 0,805 & Reliabel \\
Orientasi pasar $\left(\mathrm{X}_{2}\right)$ & Orientasi Pesaing & 0,797 & Reliabel \\
& Koordinasi & 0,803 & Reliabel \\
Kinerja perusahaan $(\mathrm{Y})$ & Antarfungsional & 0,802 & Reliabel \\
\hline
\end{tabular}

Sumber: Data diolah, 2018

Hasil uji reliabilitas yang disajikan dalam Tabel 4. menunjukkan bahwa seluruh instrumen penelitian memiliki koefisien Cronbach's Alpha lebih dari 0,60. Jadi dapat dinyatakan bahwa seluruh variabel telah memenuhi syarat reliabilitas atau kehandalan sehingga dapat digunakan untuk melakukan penelitian.

Uji normalitas ini bertujuan untuk mengetahui apakah residual dari model regresi yang dibuat berdistribusi normal atau tidak. Dalam penelitian ini uji normalitas dilakukan dengan menguji normalitas residual dengan menggunakan uji Kolmogorov-Smirnov. Jika probabilitas signifikansi nilai residual lebih besar dari 0,05 maka data tersebut dikatakan berdistribusi normal. Demikian pula sebaliknya, jika probabilitas signifikansi residual lebih rendah dari 0,05 maka data tersebut dikatakan tidak berdistribusi normal.

Tabel 5.

Hasil Uji Normalitas

\begin{tabular}{lc}
\hline & Unstandardized Residual \\
\hline $\mathrm{N}$ & 90 \\
Kolmogorov-Smirnov $Z$ & 0,522 \\
Asymp.Sig.(2-tailed) & 0,948 \\
\hline
\end{tabular}

Sumber: Data diolah, 2018

Berdasarkan hasil analisis pada Tabel 5. didapat nilai signifikansi sebesar 0,948 seperti yang ditunjukkan oleh Tabel 5. Oleh karena nilai signifikansi uji Kolmogorov-Smirnov lebih dari 0,05 maka dapat disimpulkan bahwa model persamaan regresi tersebut berdistribusi normal. 
Uji multikolinearitas bertujuan untuk menguji apakah dalam satu model regresi ditemukan adanya korelasi antar variabel bebas. Model regresi yang baik adalah tidak terjadi korelasi diantara variabel bebas. Untuk mendeteksi ada atau tidaknya korelasi antar variabel bebas dapat dilihat dari nilai tolerance dan nilai variance inflation factor (VIF).Jika nilai tolerance lebih dari $10 \%$ atau VIF kurang dari 10, maka dapat dikatakan model telah bebas dari multikolinearitas.

Tabel 6.

Hasil Uji Multikoleniaritas

\begin{tabular}{lccc}
\hline \multicolumn{1}{c}{ Variabel } & Tolerance & VIF & Keterangan \\
\hline Orientasi teknologi $\left(\mathrm{X}_{1}\right)$ & 0,838 & 1,193 & Bebas multikolinieritas \\
Orientasi pasar $\left(\mathrm{X}_{2}\right)$ & 0,838 & 1,193 & Bebas multikolinieritas \\
\hline Sumber: Data diolah, 2018 & & &
\end{tabular}

Berdasarkan Tabel 6. dapat dilihat bahwa nilai tolerance dan VIF dari seluruh variabel tersebut menunjukkan bahwa nilai tolerance untuk setiap variabel lebih besar dari 10\% dan nilai VIF lebih kecil dari 10 yang berarti model persamaan regresi bebas dari multikolinearitas.

Uji heteroskedastisitas ini bertujuan untuk mengetahui apakah dalam model regresi terjadi ketidaksamaan varians dari residual satu pengamatan ke pengamatan lain yang dilakukan dengan uji Glejser. Model regresi yang baik adalah yang tidak mengandung gejala heteroskedastisitas atau mempunyai varians yang homogen. Jika variabel bebas yang diteliti tidak mempunyai pengaruh signifikan atau nilai signifikansinya lebih dari 0,05 terhadap nilai absolute residual, berarti model regresi tidak mengandung gejala heteroskedastisitas. Hasil pengujian heteroskedastisitas disajikan pada Tabel 7 berikut.

Tabel 7.

Hasil Uji Heteroskedastisitas

\begin{tabular}{ccc}
\hline Variabel & Signifikansi & Keterangan \\
\hline Orientasi teknologi $\left(\mathrm{X}_{1}\right)$ & 0,278 & Bebas Heteroskedastisitas \\
Orientasi pasar $\left(\mathrm{X}_{2}\right)$ & 0,315 & Bebas Heteroskedastisitas \\
\hline
\end{tabular}

Sumber: Data diolah, 2018

Pada Tabel 7. dapat dilihat bahwa nilai Signifikansi dari variabel Orientasi teknologi sebesar 0,278, dan orientasi pasar sebesar 0,315. Nilai tersebut lebih besar dari 0,05 yang berarti tidak terdapat pengaruh antara variabel bebas terhadap absolute residual. Dengan demikian, model yang dibuat tidak mengandung gejala heteroskedastisitas.

Berdasarkan uraian di atas, menunjukkan bahwa semua uji asumsi klasik sudah terpenuhi sehingga hasil analisis regresi layak untuk dibahas lebih lanjut.

Setelah semua asumsi klasik terpenuhi, maka selanjutnya memaparkan hasil analisis regresi linier berganda. Perhitungan koefisien regresi linier bergandadilakukan dengan analisis regresi melalui software SPSS 18.0 for Windows, diperoleh hasil yang ditunjukan pada Tabel 8. 
Tabel 8.

Hasil Analisis Regresi Linier Berganda

\begin{tabular}{|c|c|c|c|c|c|}
\hline \multirow[t]{2}{*}{ Model } & \multicolumn{2}{|c|}{$\begin{array}{l}\text { Unstandardized } \\
\text { Coefficients }\end{array}$} & \multirow{2}{*}{$\begin{array}{c}\text { Standardized } \\
\text { Coefficients } \\
\text { Beta }\end{array}$} & \multirow[b]{2}{*}{$\mathbf{t}$} & \multirow[b]{2}{*}{ Sig. } \\
\hline & B & Std. Error & & & \\
\hline (Constant) & 1,521 & 1,438 & & 1,057 & 0,293 \\
\hline Orientasi teknologi & 0,304 & 0,065 & 0,368 & 4,680 & 0,000 \\
\hline Orientasi pasar & 0,240 & 0,037 & 0,511 & 6,496 & 0,000 \\
\hline R Square & & & 0,548 & & \\
\hline F hitung & & & 52,801 & & \\
\hline Signifikansi F & & & 0,000 & & \\
\hline
\end{tabular}

Berdasarkan hasil analisis regresi linier berganda seperti yang disajikan pada Tabel 8. maka dapat dibuat persamaan regresi sebagai berikut:

$$
\mathrm{Y}=1,521+0,304 \mathrm{X}_{1}+0,240 \mathrm{X}_{2}
$$

Nilai koefisien regresi masing-masing variabel bebas bernilai positif dengan nilai signifikansi uji t kurang dari 0,05 . Hal ini menunjukkan bahwa semua variabel bebas memiliki pengaruh positif yang signifikan terhadap variabel terikat. Berikut penjelasan mengenai hasil analisis regresi moderasi, terdiri atas koefisien determinasi ( $\mathrm{R}^{2}$ ), uji kelayakan model (uji F), dan uji hipotesis (uji t).

Koefisien determinasi $\left(\mathrm{R}^{2}\right)$ digunakan untuk mengetahui dan mengukur kemampuan model dalam menerangkan variasi variabel independen. Besarnya pengaruh variabel bebas terhadap variabel terikat yang ditunjukkan oleh nilai determinasi total (R Square) sebesar 0,548 mempunyai arti bahwa sebesar 54,8\% variasi Kinerja perusahaan dipengaruhi oleh variasi orientasi teknologi, dan orientasi pasar, sedangkan sisanya sebesar $45,2 \%$ djelaskan oleh faktor lain yang tidak dimasukkan ke dalam model.

Uji kelayakan model regresi bertujuan untuk mengetahui apakah semua variabel bebas yang diidentifikasi (orientasi teknologi, orientasi pasar) tepat digunakan memprediksi kinerja perusahaan. Uji ini sering juga disebut dengan uji F. Hasil pengolahan data pada Lampiran 9 dengan menggunakan program SPSS diperoleh nilai $F_{\text {hitung }}$ sebesar 52,801 dengan signifkansi sebesar $0,000<0,05$, maka dapat disimpulkan bahwa pada kelompok yang diuji memiliki perbedaan yang nyata (signifikan). Hasil ini mempunyai arti bahwa secara simultan orientasi teknologi, dan orientasi pasar berpengaruh signifikan terhadap kinerja perusahaan.

Berdasarkan hasil analisis pengaruh orientasi teknologi terhadap kinerja perusahaan diperoleh nilai signifikansi sebesar 0,000 dengan nilai koefisien regresi positif sebesar 0,304 Nilai signifikansi $0,000<0,05$ mengindikasikan bahwa $\mathrm{H}_{0}$ ditolak dan $\mathrm{H}_{1}$ diterima. Hasil ini mempunyai arti bahwa orientasi teknologi berpengaruh positif dan signifikan terhadap kinerja perusahaan pada hotel melati di Kecamatan Ubud, Gianyar.

Berdasarkan hasil analisis pengaruh orientasi pasar terhadap kinerja perusahaan diperoleh nilai signifikansi sebesar 0,000 dengan nilai koefisien regresi positif sebesar 0,240 . Nilai signifikansi $0,000<0,05$ mengindikasikan bahwa $\mathrm{H}_{0}$ ditolak dan $\mathrm{H}_{2}$ diterima. Hasil ini mempunyai arti bahwa orientasi pasar 
berpengaruh positif dan signifikan terhadap kinerja perusahaan pada hotel melati di Kecamatan Ubud, Gianyar.

Hasil analisis menunjukkan bahwa orientasi teknologi berpengaruh positif dan signifikan terhadap kinerja perusahaan. Hal ini berarti bahwa semakin baik penerapan orientasi teknologi pada hotel melati di Kecamatan Ubud, Gianyar maka akan berpengaruh pada semakin meningkatnya kinerja perusahaan pada hotel melati di Kecamatan Ubud, Gianyar tersebut. Begitu pula sebaliknya, semakin buruk penerapan orientasi teknologi maka akan berpengaruh pada semakin berkurangnya kinerja perusahaan pada hotel melati di Kecamatan Ubud, Gianyar tersebut.

Hasil tersebut mengindikasikan bahwa nilai - nilai yang terkandung dalam orientasi teknologi mampu dipersepsikan dengan baik dan berdampak nyata terhadap kinerja hotel melati di Kecamatan Ubud, Gianyar. Orientasi teknologi yang diukur berdasarkan indikator: penggunaan teknologi internet, mempercepat layanan kepada pelanggan, mendukung proses inovasi produk dan kemudahan dalam mengoprasionalkan terbukti mampu meningkatkan kinerja hotel melati di Kecamatan Ubud, Gianyar. Temuan ini dapat diartikan bahwa apabila intensitas penerapan orientasi teknologi oleh seluruh hotel melati di Kecamatan Ubud, Gianyar ditingkatkan, maka akan mampu memberikan kontribusi yang signifikan terhadap keberhasilan kinerja yang dicapai oleh hotel melati di Kecamatan Ubud, Gianyar.

Penelitian ini sesuai dengan hasil penelitian yang dilakukan oleh Buhalis \& Law (2001) yang menyatakan bahwa diterapkannya orientasi teknologi membuat manajemen akan lebih mudah mengkomunikasikan, mendistribusikan dan memasarkan produk mereka kepada wisatawan di seluruh dunia dengan biaya dan waktu yang efisien, sehingga dapat meningkatkan kinerja perusahaan. Hasil penelitian ini juga mendukung temuan Wulandari (2015) yang menyatakan bahwa terdapat hubungan yang positif dan kuat antara teknologi informasi terhadap kinerja perusahaan. Temuan ini memberi makna bahwa orientasi teknologi merupakan pendorong dalam meningkatkan kinerja perusahaan, semakin tinggi orientasi teknologi, hasil kinerja perusahaan juga menjadi meningkat. Hasil penelitian ini diharapkan dapat memberikan pemahaman kepada hotel melati di Kecamatan Ubud, Gianyar bahwa orientasi teknologi memiliki peran penting dalam meningkatkan kinerja perusahaan.

Hasil analisis dalam penelitian ini menunjukkan bahwa orientasi pasar berpengaruh positif dan signifikan terhadap kinerja perusahaan. Hal ini berarti bahwa semakin tinggi orientasi pasar yang dilakukan hotel melati di Kecamatan Ubud, Gianyar, maka akan berpengaruh pada meningkatnya kinerja perusahaan. Begitu pula sebaliknya, semakin rendah penerapan orientasi pasar yang dilakukan oleh hotel melati di Kecamatan Ubud, Gianyar maka kinerja yang dihasilkan akan semakin berkurang.

Hasil tersebut mengindikasikan bahwa nilai - nilai yang terkandung dalam orientasi pasar mampu dipersepsikan dengan baik dan berdampak nyata terhadap kinerja hotel melati di Kecamatan Ubud, Gianyar. Orientasi pasar yang diukur berdasarkan dimensi: orientasi pelanggan, oorientasi pesaing dan koordinasi antarfungsional terbukti mampu meningkatkan kinerja hotel melati di Kecamatan 
Ubud, Gianyar. Temuan ini dapat diartikan bahwa apabila intensitas penerapan orientasi pasar oleh seluruh hotel melati di Kecamatan Ubud, Gianyar ditingkatkan, maka akan mampu memberikan kontribusi yang signifikan terhadap keberhasilan kinerja yang dicapai oleh hotel melati di Kecamatan Ubud, Gianyar.

Penelitian ini sesuai dengan penelitian Jayaningrum \& Sanawiri (2018) yang menyatakan bahwa orientasi pasar berpengaruh positif signifikan terhadap kinerja yaitu semakin tinggi orientasi pasar maka derajat kinerja perusahaan semakin tinggi. Orientasi pasar mencerminkan kompetensi dalam memahami pelanggan, karena itu mempunyai peluang memberi kepuasan pada pelanggan Hasil penelitian ini juga mendukung temuan Adiputra \& Kusumadmo (2016) yang menemukan bahwa orientasi pasar (orientasi pada konsumen, orientasi pada pesaing, koordinasi antar fungsi) memiliki pengaruh yang positif dan signifikan terhadap kinerja perusahaan. Hasil penelitian ini diharapkan dapat memberikan pemahaman kepada hotel melati di Kecamatan Ubud, Gianyar bahwa orientasi pasar memiliki peran dan tujuan penting dalam meningkatkan kinerja perusahaan.

Hasil penelitian menunjukkan bahwa orientasi teknologi dan orientasi pasar memberikan pengaruh yang positif dan signifikan terhadap kinerja perusahaan. Implikasi dari hasil penelitian yang didapat mampu menjadikan tambahan pengetahuan, referensi dan bahan pertimbangan bagi pihak manajemen hotel melati di Kecamatan Ubud, Gianyar dalam proses pengambilan keputusan dan penetapan kebijakan perusahaan untuk meningkatkan kinerja perusahaan.

Hotel melati di Kecamatan Ubud, Gianyar perlu meningkatkan dan mempertahankan penggunaan teknologi internet, mempercepat layanan kepada pelanggan, mendukung proses inovasi produk, dan kemudahan dalam mengoperasionalkan agar orientasi teknologi dapat tercapai maksimal. Kemudian, orientasi pelanggan, orientasi pesaing dan koordinasi antarfungsional perlu dipertahankan bahkan ditingkatkan selalu agar orientasi pasar terlaksana dengan optimal, sehingga kinerja perusahaan dapat meningkat. Jika orientasi teknologi dan orientasi pasar ini mampu diterapkan dan dijalankan dengan baik, maka kinerja perusahaan pada hotel melati di Kecamatan Ubud, Gianyar yang dihasilkan akan semakin membaik

\section{SIMPULAN}

Orientasi teknologi berpengaruh positif dan signifikan terhadap kinerja perusahaan. Hasil penelitian ini memiliki arti bahwa semakin baik penerapan orientasi teknologi yang diukur berdasarkan indikator: penggunaan teknologi internet, mempercepat layanan kepada pelanggan, mendukung proses inovasi produk dan kemudahan dalam mengoprasionalkan pada hotel melati di Kecamatan Ubud, Gianyar maka akan berpengaruh pada semakin meningkatnya kinerja perusahaan pada hotel melati di Kecamatan Ubud, Gianyar tersebut. Orientasi pasar berpengaruh positif dan signifikan terhadap kinerja perusahaan. Hasil penelitian ini memiliki arti bahwa semakin tinggi orientasi pasar yang dilakukan hotel melati di Kecamatan Ubud, Gianyar, maka akan berpengaruh pada meningkatnya kinerja perusahaan. Orientasi pasar yang diukur berdasarkan dimensi: orientasi pelanggan, oorientasi pesaing dan koordinasi antarfungsional terbukti mampu meningkatkan kinerja hotel melati di Kecamatan Ubud, Gianyar. 
Penelitian ini dapat dijadikan rujukan bagi manajemen perusahaan untuk mengambil keputusan. Mempercepat layanan kepada pelanggan merupakan indikator dengan skor terendah pada variabel orientasi teknologi. Hal ini dikarenakan tidak semua perusahaan mampu memberikan pelayanan yang sigap kepada pelanggan dalam proses booking online melalui website hotel. Oleh karena itu, pihak perusahaan sebaiknya memberikan pelatihan dan pendidikan pada karyawannya mengenai cara penggunaan teknologi dan pelayanan prima agar mampu memberikan pelayanan yang sigap kepada pelanggan dalam proses booking online melalui website hotel. Koordinasi antarfungsional merupakan indikator dengan skor terendah pada variabel orientasi pasar. Hal ini dikarenakan tidak semua fungsional dalam perusahaan dapat berkontribusi dalam menciptakan nilai pelanggan, serta memiliki strategi yang terintegrasi dalam melayani pelanggan. Selain itu, belum semua hotel melati di Kecamatan Ubud, Gianyar responsif dalam melayani kebutuhan dan permintaan pelanggan, sehingga hal tersebut perlu di evaluasi dan ditingkatkan kembali, agar orientasi pasar pada hotel melati di Kecamatan Ubud, Gianyar dapat tercapai dengan optimal.

Target pasar merupakan indikator dengan skor terendah pada variabel kinerja perusahaan. Hal ini disebabkan karena belum semua hotel melati di Kecamatan Ubud, Gianyar mampu mencapai penjualan yang lebih baik dibandingkan pesaingnya selama 3 tahun terakhir. Oleh karena itu untuk meningkatkan kinerja perusahan menjadi lebih maksimal, maka seluruh hotel melati di Kecamatan Ubud, Gianyar sebaiknya selalu mengevaluasi dan meningkatkan target pasarnya agar mampu mencapai penjualan yang lebih baik dibandingkan pesaingnya.

Penelitian selanjutnya diharapkan dapat menambah variabel-variabel lain yang sejalan dengan peningkatan kinerja perusahaan seperti inovasi produk agar hasil dapat terdefinisi menjadi lebih baik, atau bisa juga menambahkan variabel mediasi dalam penelitian ini. Selain itu, sampel serta ruang lingkup penelitian dapat diperluas dan tidak hanya terbatas pada Kecamatan Ubud saja.

\section{REFERENSI}

Adiputra, R., \& Kusumadmo, E. (2016). Pengaruh Orientasi Pasar Terhadap Kinerja Perusahaan (Studi pada Hotel Kelas Melati di Yogyakarta). Jurnal Manajemen Fakultas Ekonomi Universitas Atma Jaya Yogyakarta, 1(2), 112.

Afsharghasemi, A., Zain, M., Sambasivan, M., \& Imam, S. N. . (2013). Market Orientation, Government Regulations, Competitive Advantage \& Internasionalzation of SMEs: A study in Malaysia. Journal of Business Administration Reasearch, 2(2), 13-22.

Ahimbisibwe, G., M, J., M, N., \& Ngoma, M. (2013). Export Market Orientation, Innovation and Performance of Fruit Exporting Firm in Uganda. European Scientific Journal, 9(4), 1-23.

Baker, W. E., \& Sinkula, J. M. (2009). The Complementary Effects of Market Orientation and Entrepreneurial Orientation on Profitability in Small 
Business. Journal of Small Business Management, 47(4), 443-464.

Buhalis, D., \& Law, R. (2001). Progress in information technology and Tourism Management: 20 Years on and 10 Years After The Internet The State of eTourism Research. Tourism Management, 29(4), 609-623.

Chiun, L. M., Azlan, A., Mohamad., T., Ramayah, \& Chai, W. Y. (2015). Examining The Effects of Leadership, Market Orientation, and Leader Member Exchange (LMX) on Organizational Performance. Engeneering Economica, 26(4), 409-421.

Direktori Hotel Kabupaten Gianyar. (2016). Daftar Hotel/Akomodasi dengan Klasifikasi Non Bintang/Melati di Kabupaten Gianyar 2015.

Felgueiraa, T., \& Gouvenia, R. (2012). Entrepreneurial Orientation, Market Orientation and Performance of Teachers and Researchers in Public Higher Education Institutions. Viesoji Politika Ir Administravimas, 11(4), 703-718.

Ferdinand, A. (2010). Manajemen Pemasaran: Sebuah Pendekatan Stratejik. Journal of Researc Paper Series, 1(1), 1-12.

Hartini, S. (2017). Hubungan Orientasi Pasar, Strategi Bersaing, Kewirausahaan Korporasi Dan Kinerja Perusahaan. Ekuitas (Jurnal Ekonomi Dan Keuangan), 17(1), 39-53.

Hasan, A. (2014). Marketing dan kasus-kasus Pilihan. Yogyakarta: CAPS.

Helia, R., Farida, N., \& Prabawani, B. (2015). Pengaruh Orientasi Pasar dan Orientasi Kewirausahaan Terhadap Keunggulan Bersaing Melalui Inovasi Produk sebagai Variabel Antara (Studi Kasus pada IKM Batik di Kampung Batik Laweyan, Solo). Diponegoro Journal of Social and Political of Science, 4(4), 1-11.

Herath, H. M. ., \& Mahmood, R. (2013). Strategic Orientation Based Research Model of SME Performance for Developing Countries. Society of Interdisciplinary Business Research, 2(1), 430-440.

Jayaningrum, E., \& Sanawiri, B. (2018). Pengaruh Orientasi Pasar, Inovasi, Orientasi Kewirausahaan Terhadap Keunggulan Bersaing Dan Kinerja Pemasaran (Studi Pada Kuliner Kafe Kota Malang) Erni. Jurnal Administrasi Bisnis (JAB)|V, 54(1), 149-158.

Jyoti, J., \& Sharma, J. (2012). Impact of market orientation on business performance: Role of employee satisfaction and customer satisfaction. Vision, 16(4), 297-313.

Kanyabi, Y., \& Devi, S. (2012). The impact of advisory services on Iranian SME 
performance: An empirical investigation of the role of professional accountants. African Journal Business Management, 43(2), 61-72.

Kara, A., John, E., Spillan, W, O., \& DeShields, J. (2005). The Effect Of a Market Orientation on Business Performance: A Study Of Small-Sized Service Retailers Using Markor Scale. Journal Of Small Business Management, 43(2), 105-118.

Kumar, V., Jones, E., Venkatesan, R., \& Leone, R. . (2011). Is market orientation a source of sustainable competitive advantage or simply the cost of competing? Journal of Marketing, 75(1), 16-30.

Law, R., \& Bai, B. (2010). Website Development and Evaluations in Tourism: A Retrospective Analysis. In: Hitz, Martin, Marianna Sigala dan Jamie Murphy. Information and Communication Technologies in Tourism, 1(2), 1-12.

Lee, C. ., Song, H. ., Lee, H. ., Lee, S., \& Bernhard, B. . (2013). The impact of CSR on casino employess organizational trust, job satisfaction, and customer orientations: An empirical examination of responsible gambling strategis. International Journal of Hospitality Management, 33(1), 406-415.

Lee, Y. ., Kim, Y. ., Son, M. ., \& Lee, D. J. (2011). Do emotions play a mediating role in the relationship between owner leadership styles and manager customer orientations, and performance in service environment? International Journal of Hospitality Management, 30(4), 942-952.

Liu, H., Ke, W., Wei, K. K., \& Zhongsheng, H. (2013). Effects of Supply Chain Integration and Market Orientation on Firm Performance: Evidence from China. International Journal of Operations \& Production Management, 33(3), 322-346.

Mandy, M. . (2009). The Relationship between Innovationess and the Performance of small and Medium-size Enterprises (SMEs) of Malaysian manufacturing sector. International Journal of Management and Innovation, 1(2), 1-14.

Maslucha, N., \& Sanaji. (2013). Pengaruh Orientasi Pasar Terhadap Kinerja Pemasaran Melalui Inovasi. Jurnal Ilmu Manajemen, 1(4), 1-12.

Menteri Pariwisata Dan Ekonomi Kreatif Republik Indonesia. (2013). Peraturan Menteri Pariwisata Dan Ekonomi Kreatif Republik Indonesia Nomor PM.53/HM.001/MPEK/2013 Tentang Standar Usaha Hotel.

Morrison, A. (2001). Hospitality and Travel Marketing. New York: Delmar.

Mudiantono, K. N. (2005). Analisis Pengaruh Faktor Lingkungan Terhadap Inovasi Produk dan Kreativitas Strategi Pemasaran Dalam Meningkatkan Kinerja 
Pemasaran (Studi Pada Perusahaan Kerajinan Keramik di Sentra Kasongan Kabupaten Bantul Yogyakarta). Jurnal Bisnis Dan Ekonomi, 12(1), 1-10.

Mulyani, I. T. (2015). Upaya Meningkatkan Kinerja Pemasaran Melalui Orientasi Pasar dan Orientasi Kewirausahaan dengan Inovasi sebagai Variabel Intervening (Studi Empiris Pada Usaha Mikro Kecil dan Menengah Kota Semarang). Universitas Diponegoro.

Narver, J. C., \& Slater, S. F. (1990). The Effect of Market Orientation on Business Profitability. Journal of Marketing, 1(2), 20 - 35.

Olusola, O. A. (2011). Accounting Skill as a Performance Factor for Small BBusinesess in Nigeria. Journal of Emerging Trends in Economics and Management Science, 24(1), 27-43.

Park, Y., \& Gretzel, U. (2006). Evaluation of Emerging Technologies in Tourism: The Case of Travel Search Engines. In: Hitz, Martin, Marianna Sigala dan Jamie Murphy. Information and Communication Technologies in Tourism, $1(1), 371-382$.

Pramesti, N. M. V., \& Giantari, I. G. A. K. (2016). Peran Orientasi Pasar Memediasi Pengaruh Orientasi Kewirausahaan terhadap Kinerja UKM Industri Kerajinan Endek. E-Jurnal Manajemen Unud, 5(9), 5754-5782.

Putri, P. I. P. (2015). Peran Inovasi Memediasi Orientasi Pasar Terhadap Kinerja Perusahaan (Studi pada perusahaan Konveksi di Kota Denpasar. Universitas Udayana.

Rong, F., Chang, E., Ou, C. C., \& Chou, C. . (2014). Internal market orientation, marker capabilities and learning orientation Perfect Translation \& Compunet. Taichung, Taiwan, and European Journal of Marketing, 48(1), 170-192.

Safarnia, H., Akbari, Z., \& Abbasi, A. (2011). Review of market orientation and competitive advantage in the industrial estates companies (Kerman, Iran): Appraisal of model by AMOS graphics. World J. Soc. Science, 1(5), 132150.

Soedjono. (2005). Pengaruh Budaya Organisasi terhadap Kinerja Organisasi dan kepuasan Kerja Karyawan pada Terminal Penumpang Umum di Surabaya. Jurnal Manajemen Dan Kewirausahaan, 7(1), 1-5.

Tjiptono, F. (2014). Strategi Pemasaran Edisi Ketiga. Yogyakarta: CV. Andi Offset.

Umar, Z. A. (2014). Peran Kemampuan Manajemen dan Orientasi Pasar sebagai Mediasi Pengaruh Orientasi Kewirausahaan Terhadap Kinerja Bisnis (Studi 
pada Industri Kecil dan Menengah Pangan di Gorontalo). Universitas Brawijaya.

Voss, G. B., \& Voss, Z. G. (2000). Strategic Orientation And Firm Performance In An Artistic Environment. Journal of Marketing, 64(1), 67-83.

Widarti, D. T. (2016). Pengaruh Orientasi Pasar dan Inovasi Produk terhadap Kineja Pemasaran (Studi kasus pada Sentra Industri Pembuatan Tahu Kecamatan Sragen Kabupaten Sragen). Universitas Negeri Semarang.

Wulandari, A. (2013). Pengaruh Orientasi Pelanggan, Orientasi Pesaing dan Inovasi Produk Terhadap Kinerja Pemasaran. Management Analysis Journal, 1(2), 110.

Wulandari, A. (2015). Pengaruh Orientasi Kewirausahaan dan Teknologi Informasi Terhadap Kinerja Perusahaan Pada PT Pawiwiri Cilegon. Jurnal Universitas Komputer Indonesia, 5(1), 1-20.

Yazdani, H., Zare, M. A. A., Nasiri, M. H., \& Asfnzhad, M. (2011). Examine the relationship between customer orientation and organizational citizenship behavior. Landscape Business Manahement, 6(1), 53-69.

Zhang, D. D., \& Bruning, E. (2011). Personal Characteristics and Strategic Orientation: Entrepreneurs in Canadia Manufacturing Companies. International Journal of Entrepreneural Behavior and Research, 17(1), 82103.

Zhou, K. Z., Brown, J. R., \& Dev, C. . (2009). Market orientation, competitive advantage, and performace: A demand-based perspective. Journal of Business Reaseach, 62(11), 1063-1070. 